It may, therefore, be thought to be a book for the specialist, but this is not so. The book makes a fascinating study for all animal lovers, and is very easy to read. The author writes lucidly from his wide research on the subject, with the result that few will fail to be entertained, and many will gain a deep interest in the welfare of fauna.

The book covers a wide range. Fresh information on the habits and behaviour of various animals is disclosed: for example, the fact that the sea otter spends much of its time floating on its back with its arms resting across its chest or using its chest as a table for its food. Odd corners of the Earth, such as the Galapagos Islands, are mentioned. Past, present and future problems are considered.

There are twenty black-and-white plates that are actual photographs. These provide rare glimpses for the layman of some animals: for example, fur seals and the Komodo dragon of Komodo Island. Photographs come from such sources as David Attenborough and Mrs. Peter Scott, as well as from scientists and zoologists of many countries.

B. J. G. Maitland

\section{The Birds of the British Isles}

By Dr. David Armitage Bannerman. Illustrated by George E. Lodge. Vol. 10: Scolopacidae (conclusion); Charadriidae; Recurvirostridae; Haematopodidae. Pp. $x+320+23$ plates. (Edinburgh and London: Oliver and Boyd, Ltd., 1961.) 63s. net.

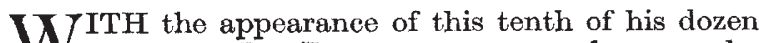
$W$ volumes, Dr. Bannerman approaches completion of his great undertaking. Here he concludes his account of the sandpiper family (mainly those species named in English from the colour of their 'shanks'), deals with the smaller number of the plovers, and ends with chapters on the avocet, the stilt, and the oystercatcher. As in the ninth volume, many of the species are more or less uncommon visitors to the British Isles from distant breeding grounds; it is therefore valuable to have the contributions that Dr. Bannerman has obtained from American, Russian and other ornithologists on aspects of life-history that could not otherwise have been fully covered. There are also British contributions on special topics such as the breeding habits of the dotterel and greenshank in Scotland, the disappearance of the Kentish plover as a British breeding bird (last known to nest in 1955), and the recovery of that status by the avocet under careful protection in East Anglia. LANDSBOROUGH THOMSON

\section{Living Fishes of the World}

By Earl S. Herald. Pp. 304 (300 illustrations). (London: Hamish Hamilton, Ltd., 1961.) 63s. net.

IAD there been fewer errors in the text, this book could have made a noteworthy addition to the list of popular works on fishes. The colour and monochrome photographs are very good, and some are surely unique. Although much of the text passes muster, there are far too many errors. Some, like the inconsistent spelling of certain specific names and placing Phallostethidae under a heading "Suborder Polynemoidea", may be due to careless proof-reading. Others cannot be so dismissed. There are unsettling contradictions; for example, we are told that the arawara (Osteoglossum) and Scleropages are both mouth-breeders, and later in the section we are told that the breeding habits of the arawara are unknown, but it is suspected of being a mouth-breeder. The author's views on external gills, their occurrence and homologies are confused. Who would agree that the external gills of Polypterus are only comparable with the embryonic gills of larval sharks, and that they are not like the external gills of lung fishes? The section dealing with cichlid breeding habits needs tightening up, and it is a pity that Tilapia melanopleura (one of the non-mouth-breeding spccies) should be used to illustrate "African Mouth-breeders". One final example: in view of the many articles and papers on the colacanth it is surprising to read that one of its "anatomical distinctions include . . . a large lung . .."; it is stretching definitions too far to deseribe this admittedly large but narrow, fatfilled and solid structure as a lung.

These and other errors could easily be corrected in a revised edition, which $I$ hope will appear, for there is a lot of valuable material in this book which the non-professional zoologist would not easily find without searching widely.

P. H. Greenwoon

The Chrysomelidae (Coleopt.) of China and Korea Part 1. By J. L. Gressitt and S. Kimoto. (Pacific Insects Monograph, No. 1A.) Pp. 300. (Honolulu, Hawaii: Entomology Department, Bernice P. Bishop Museum, 1961.) 4 dollars; $29 s$.

$A \mathrm{~S}$ the authors state in their introduction, the A Chrysomelidae is one of the largest families of beetles. It probably includes more than 50,000 species in the world. Therefore, any modern work dealing comprehensively with the family as found in a single zoogeographical region of the world is to be welcomed. Unfortunately, it falls between two stools. It is more than a simple catalogue, but much less than a comprehensive hand-book to the fauna of the region. In short, the authors seem to have attempted to do too much in too little time and above all, space. It is a pity that this work was not modelled on that invaluable contribution to our knowledge of the Chrysomelidae, the three volumes by S. Maulik in the Fauna of India.

The illustrations in the present work are superb and the descriptions of new species good. The keys to the sub-families, genera and species are clear and a very valuable tool to all workers on the group. The authors are to be congratulated on the monumental effort needed for their compilation. However, it would be useful to have short descriptions and notes on each genus and species. One would then be able to check identifications and to determine new species. It is pleasing to find that the host plants are stated where known; but fuller biological notes on both larvæ and adults would be useful. It is to be hoped that the final volumes of the Chrysomelidae will include a comprehensive and easily used index at the back. The format of the Insects of Hawaii is to be recommended for all future volumes.

B. J. Selman

\section{The Yorkshire Jurassic Flora}

By Prof. Thomas Maxwell Harris. 1: ThallophytaPteridophyta. Pp. ix +212 . 71 text-figs. (London: British Museum (Natural History), 1961.) 80s. net.

THIS is the first of two volumes on the Jurassic flora of Yorkshire. The discoveries of fossil plants made since the early part of the nineteenth century in Yorkshire have probably contributed more to our knowledge of Jurassic plants than those made 